\title{
Heritability estimates for body weight and height at withers in Brazilian army horses
}

\author{
Estimativas de herdabilidade para peso corporal e altura de cernelha de equinos do Exército Brasileiro
}

\author{
Priscilla Regina Tamioso ${ }^{\mathrm{I} *}$ Tiago Rafael Cosmo \\ Concepta Margaret McManus Pimentel ${ }^{\mathrm{II}}$ Laila Talarico Dias ${ }^{\mathrm{I}}$ Rodrigo de Almeida Teixeira $^{\mathrm{I}}$
}

\begin{abstract}
The aim of this study was to estimate the heritability for weight and height at withers of 260-780 days of age No Defined Breed (NDB) horses, at intervals of 40 days, which belong to the Brazilian Army cavalry. Thus, the model considered the direct genetic effects as random ones, as fixed, the effects of sex and year of birth and the linear effects of height at withers and age, as covariates for the analysis of body weight, whereas for the analysis of height, the linear effect of weight was included as a covariate. For the complete data, the estimated heritability coefficients were $0.40 \pm 0.034$ and $0.70 \pm 0.019$ for weight and height at withers, respectively, indicating that individual selection for these traits may be effective. On the other hand, for the data subdivided into age classes, the heritability coefficients ranged between 0.04 and 0.77 for weight, with the highest estimation for the class between 440 and 480 days of age, which indicates a higher possibility of weight selection during this period. For height, the heritability values ranged between 0.08 and 0.98 , being the highest estimate found between 300 and 340 days of age, corroborating, thus, to the selection of the trait at this age.
\end{abstract}

Key words: cavalry, growth traits, selection.

\section{RESUMO}

Objetivou-se estimar a herdabilidade para peso e altura de cernelha de equinos sem raça definida (SRD), pertencentes à cavalaria do Exército brasileiro, com idades entre 260 e 780 dias, em intervalos de 40 dias. Assim, o modelo utilizado considerou os efeitos genéticos aditivos diretos como aleatórios, os efeitos de sexo e ano de nascimento como fixos e os efeitos lineares de altura de cernelha e idade do animal, como covariáveis para análise do peso corporal, sendo que, para análise da altura, o efeito linear do peso foi incluído como covariável. Para o arquivo completo, os coeficientes de herdabilidade estimados foram $0,40 \pm 0,034$ e $0,70 \pm 0,019$, para peso e altura de cernelha, respectivamente, indicando que a seleção individual para essas características pode ser eficiente. Entretanto, para os arquivos subdivididos em classes de idade, os coeficientes de herdabilidade variam entre 0,04 e 0,77 para peso, sendo a maior estimativa obtida para a classe entre 440 e 480 dias de idade, o que indica maior possibilidade de seleção para peso nesse período. Para altura, as herdabilidades oscilaram entre 0,08 e 0,98, sendo a maior estimativa encontrada entre 300 e 340 dias de idade, corroborando a seleção da característica nesta idade.

Palavras-chave: cavalaria, características de crescimento, seleção.

\section{INTRODUCTION}

For horses, the main objective of the selection is the improvement of traits related to the conformation and the gait of the animals. In Brazil, although the horse breeders associations require a performance registration of these animals, this information is not always used in order to improve the genetic performance of this species. For the Brazilian Army horses, both the conformation and the gait are important traits, once the patrol, the frontier guard and instruction fields throughout the national territory for military ceremonial and sporting practices such as jumping, horse riding events, polo and horse training are the most developed activities by the animals of the segment (DLog, 2003). Because of the wide range of

'Departamento de Zootecnia, Universidade Federal do Paraná (UFPR), 83035-050, Curitiba, PR, Brasil. E-mail: priscillatamioso@gmail.com. *Autor para correspondência.

"Departamento de Zootecnia, Universidade Federal do Rio Grande do Sul (UFRGS), Porto Alegre, RS, Brasil. 
functions required for the horses, it is not easy to obtain animals with versatility and adaptability for all activities, taking into consideration the different environments in which they are raised in Brazil.

Therefore, searching for suitable horses for military service will depend on assessments that enable the identification of genetically superior sires for the formation of an animal population with traits that meet the demands of military regiment. As a result, to determine which traits may be used as selection criterion, the estimation of genetic parameters is needed. However, few studies in the literature have estimated genetic parameters for growth traits for this species, and the available information were obtained at predetermined age groups.

\section{MATERIAL AND METHODS}

Data

Data from 1766 No Defined Breed (NDB) horses, born between 1994 and 2001, progeny of 37 stallions and 217 mares belonging to Military Organizations, centered on São Borja stud farm, in Rio Grande do Sul, south of Brazil, were analyzed. The height at withers and weight of the animal were measured repeatedly throughout its life, from six months of age to adulthood. The ones without information of birth date, parents, weight or height, born before 1978 and individuals aged outside the range (260 to 780 days) were eliminated from the dataset.

Firstly, the analysis was performed with the full dataset with animals from 260 to 780 days of age, to estimate the heritability coefficient for body weight and height at withers. For body weight, the effects of sex and year of birth were considered as fixed, and, as covariates, the linear and quadratic effects of height and age. On the other hand, for the height, the model included the same fixed effects considered for weight and, as covariates, the linear and quadratic effects of weight and age.

After obtaining the estimates for the full set, the files were re-edited and data on weight or height at withers were separated at intervals of 40 days of age, overlapping every 20 days, according to the following age groups: 260-300 days, 280-320 days, 300-340 days, and so on, up to 740-780 days, producing 25 files (Table 1 ). Intervals of 40 days of age were considered, once few animals would remain in each class, as proposed by ALBUQUERQUE \& MEYER (2001a) and DIAS et al. (2005), in studies with similar datasets.

Due to the small age range in each class, it was not possible to identify the quadratic effects. For this reason, only the linear effects were considered in
Table 1 - Number of horses used for analysis and their distribution over age classes.

\begin{tabular}{lc}
\hline Age classes & $\mathrm{N}^{\circ}$ of animals \\
\hline $260-300$ & 96 \\
$280-320$ & 92 \\
$300-340$ & 92 \\
$320-360$ & 92 \\
$340-380$ & 82 \\
$360-400$ & 94 \\
$380-420$ & 94 \\
$400-440$ & 140 \\
$420-460$ & 147 \\
$440-480$ & 123 \\
$460-500$ & 119 \\
$480-520$ & 130 \\
$500-540$ & 159 \\
$520-560$ & 177 \\
$540-580$ & 177 \\
$560-600$ & 177 \\
$580-620$ & 177 \\
$600-640$ & 213 \\
$620-660$ & 186 \\
$640-680$ & 186 \\
$660-700$ & 176 \\
$680-720$ & 168 \\
$700-740$ & 145 \\
$720-760$ & 128 \\
$740-780$ & 102 \\
\hline
\end{tabular}

the analyses of the subclass datasets (each file) and the heritability coefficients were estimated from them. After creating the age classes, animals with no record of height or weight, without information of birth date and individuals with unknown sires and dams were removed.

In this study, the maternal effect was tested, but it was not significant, since the animals had been weaned prematurely, around 120 days of age and, also, there were few foals per mare.

Statistical methods

Estimates of (co) variance and heritability were obtained by the derivative-free restricted maximum likelihood, using the MTDFREML program (BOLDMAN et al., 1995), assuming the following statistical model: $\mathrm{Y}=\mathrm{X} \beta+\mathrm{Za}+\mathrm{e}$ where $\mathrm{Y}$ is the vector of phenotypic records; $\beta$ is the vector of fixed effects in the model; $\mathrm{a}$ is the vector of the direct genetic effects; $\mathrm{X}$ and $\mathrm{Z}$, the incidence matrices associated to each random effect, respectively, and e is the vector of random errors associated to each observation. 


\section{RESULTS AND DISCUSSION}

Means for weight, withers height and age at measurement of the animals were $364 \pm 64.11 \mathrm{~kg}$, $1.46 \pm 0.06 \mathrm{~m}$ and $542.5 \pm 137.5$ days, respectively. Asimilar result was observed by OLIVEIRA et al. (2008), finding the means of $360 \mathrm{~kg}$ for weight and $1.42 \mathrm{~m}$ for height, for No Defined Breed horses, which belong to the Military Police Cavalry Squadron, in Piauí State, Brazil.

For the height at withers, it was noticed that the linear and quadratic effect of body weight influenced the expression of the trait $(\mathrm{P}<0.01)$. However, for the weight analysis, considering each class, the linear effect of height was significant $(\mathrm{P}<0.01)$. Figure 1 shows the behavior of estimated body weight and height at withers, according to the age (in days).

As can be seen from figure 1, during the period of study, body weight increased until around two years old, and after this period, it began to stabilize. Observing the withers height, there is a gradual increase, stabilizing around $1.5 \mathrm{~m}$ at two years and a half.

As expected, withers height and weight of animals increased according to the age class, as well as when studied simultaneously, i.e., as the height at withers increases, the weight values also increase gradually (Figure 2). For Lipizzan horses, the growth dynamics for withers height and weight gain was more pronounced up to 200 days (LOVSIN et al., 2001). On the other hand, for Hanoverian horses, VERVUERT et al. (2003) observed that foals at seven months of age reached $83 \%$ of the withers height when adults and the average height was of $1.67 \mathrm{~m}$. Finally, BROWNDOUGLAS \& PAGAN (2006), assessing Thoroughbred horses from five different locations (Australia, England, India, New Zealand and Kentucky) reported a gradual increase in withers height of approximately $1.60 \mathrm{~m}$ and in weight of about $500 \mathrm{~kg}$, up to the evaluated age (560 days).

The heritability coefficients $\left(h^{2}\right)$ for the complete dataset were $0.40 \pm 0.03$ for weight and $0.70 \pm 0.019$ for the height at withers. For horses, it is known that traits related to conformation (wither height, croup height, body length, chest width, among others) have moderate to high values of heritability, with large fluctuations. HINTZ et al. (1978), working with Thoroughbred horses, reported heritability values of high magnitude for weight $(0.90 \pm 0.05)$ and withers height $(0.88 \pm 0.05)$, indicating that it is possible to obtain genetic progress at around 18 months of age (450-714 days).

When the heritability for weight was estimated as a function of age class, it is noteworthy that the estimates for weight ranged from $0.04( \pm 0.29)$ and $0.77( \pm 0.33)$. Higher values were found between 420 and 480 days of age, being the highest estimate obtained in the age-class between 440 and 480 days. After 480 days of age, the estimates decreased to close to 580 days $(0.07)$, returning to oscillate between valleys and peaks, reaching 0.22 at 760 days, as shown in figure 3 . The files related to the ages 300-340, 320-360, 380-420, 500-540, 520-560 and 660-700 days did not converged.

High heritability values for weight were also estimated by CAMPOS et al. (2007) for No Defined Breed horses, with heritability values for weight at two,

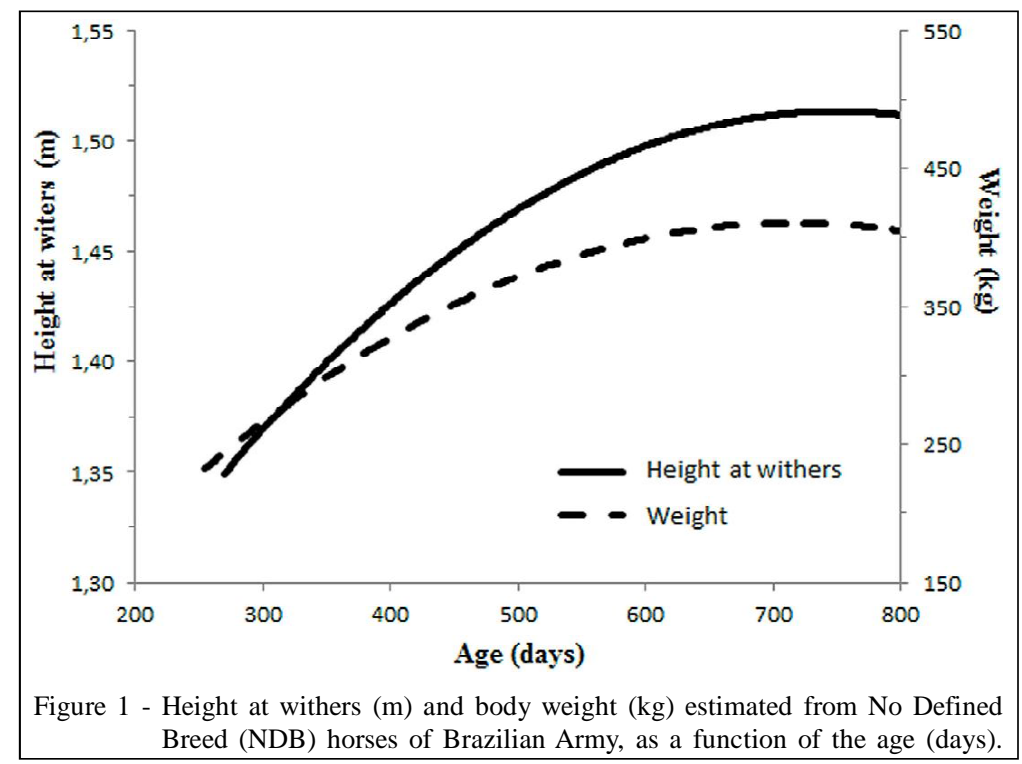

Ciência Rural, v.42, n.12, dez, 2012. 


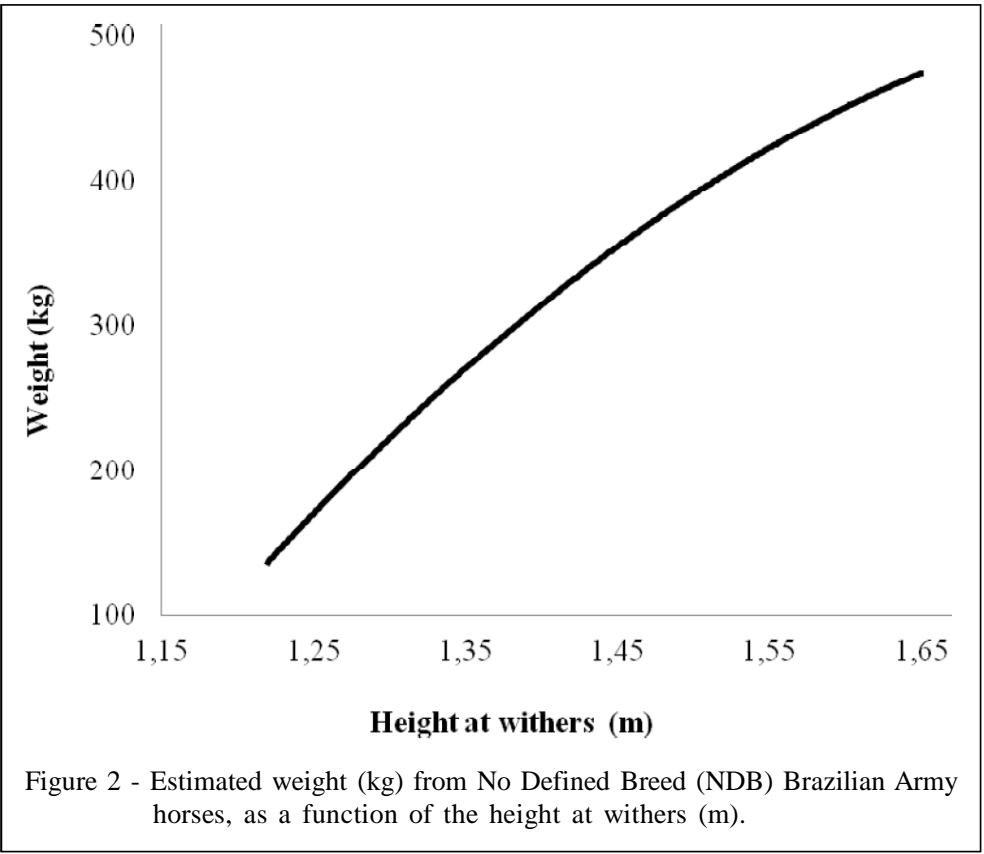

three and four years of age equal to $0.60,0.52$ and 0.56 , respectively. According to LAWRENCE \& FOWLER (2002), the weights at younger ages tend to present lower heritability when compared to older animals, probably due to a greater influence of the maternal effect on the initial weights than on the post-weaning weights. In the same way, working with Nelore cattle, ALBUQUERQUE \& MEYER (2001b) obtained estimates of heritability for birth weight of 0.13 , which increased with age, reaching 0.25 at 570-600 days of age.
When estimated the heritability for withers height in classes of age, there is a variation between $0.08( \pm 0.18)$ and $0.98( \pm 0.47)$, being the highest estimate obtained for the class 300 to 340 days of age, decreasing thereafter to close to 420 days of age, ranging from that period. After 600 days of age, there is great variation reaching the value of $0.26( \pm 0.32)$ at around 740 days, as shown in figure 4 .

In relation to the curves of heritability for weight and height at withers, it is possible to notice an

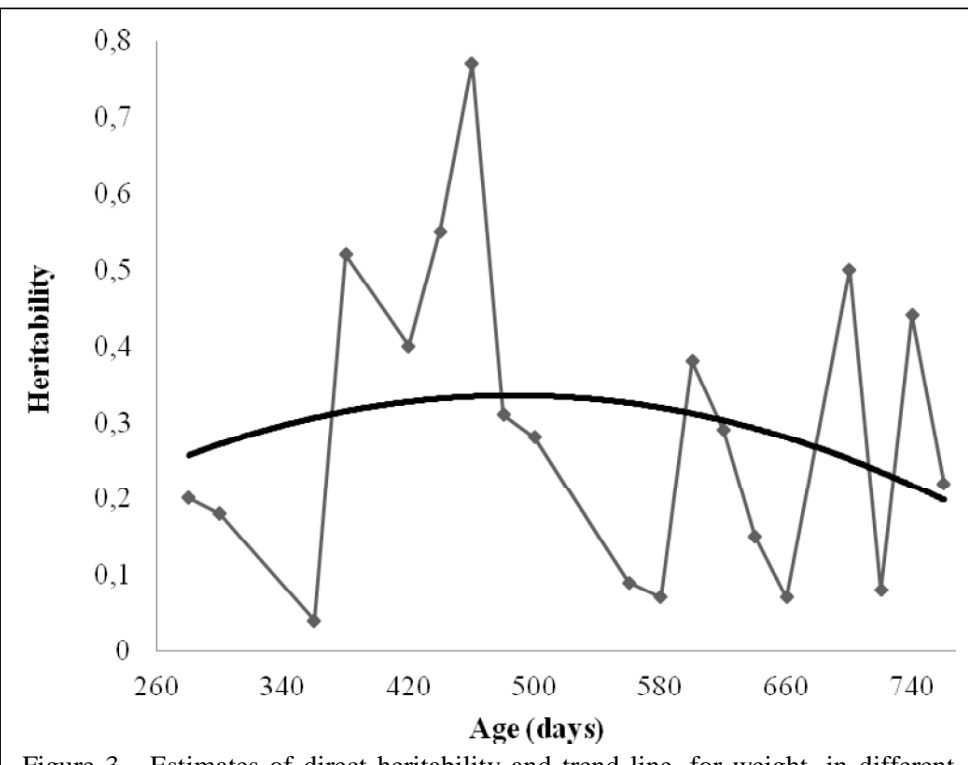

Figure 3 - Estimates of direct heritability and trend line, for weight, in different ages of NDB Brazilian Army horses. 


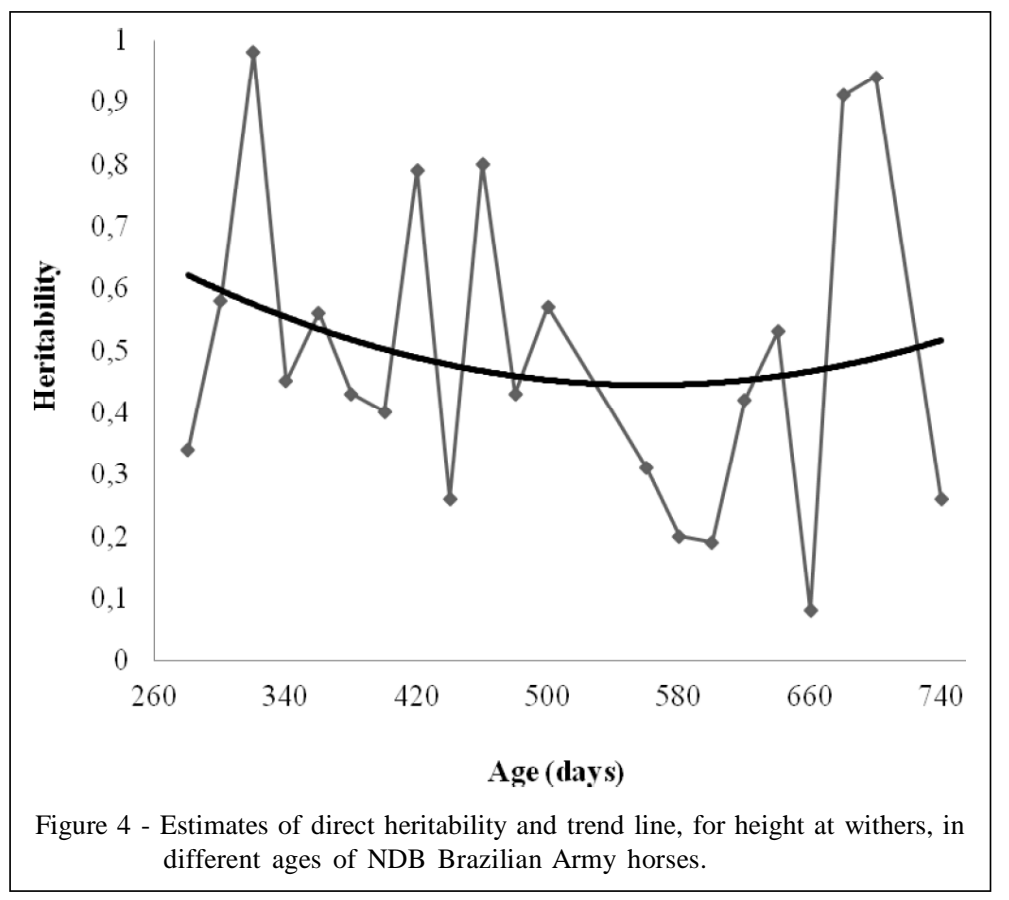

antagonistic behavior, tended to higher estimates for weight and lower for height at withers next to 500 days of age. It indicates higher genetic variability for the linear measurement during growth phases in these animals and the direct selection would be more efficient, but the same is not true for withers height. If the producer selects more robust and less wading horses, he might obtain positive results.

For withers height, HINTZ et al. (1978), in a study with Thoroughbred horses (0-714 days), found moderate to high heritability coefficients, which ranged from $0.33 \pm 0.04$ to $0.88 \pm 0.05$. On the other hand, KOENEN et al. (1995), evaluating 3 to 7 year-old Dutch Warmblood mares, estimated heritability values of 0.19 and 0.20 for length and height at withers, respectively, although SAMORE et al. (1997), analyzing Haflinger horses at 30 months old of age, obtained heritability values of 0.26 for height at withers. For the same trait, ZECHNER et al. (2001) reported high heritability coefficients (0.52) for 4-year-old or more Lipizzan stallions and mares. Likewise, DRUML et al. (2006) found values of heritability $(0.67 \pm 0.02)$ for height at withers of Noriko horses from 1 to 5 years old. The same was observed for Belgian Warmblood mares of three years old, when RUSTIN et al. (2009) estimated heritability for height at withers and length of $0.34 \pm 0.06$ and $0.33 \pm 0.06$, respectively, and SCHRODERUS \& OJALA (2010) for height at withers for Finnhorse foals (1-3 years old) $(0.89 \pm 0.00)$ and American Trotter (1-2 years old)
$(0.89 \pm 0.01)$, being the genetic progress expected from direct selection for this trait.

For height, the values of heritability estimated ranged between 0.08 and 0.98 and the highest estimate was found between 300 and 340 days of age. Hence, from the heritability coefficients, it will be possible to perform selection. In Brazil, for this trait, the heritability reported was low. For No Defined Breed and Brazilian Show jumper horses, CAMPOS et al. (2007) estimated heritability values equal to $0.01,0.08$, 0.08 and 0.02 and $0.04,0.12,0.00$ and 0.0 , at 1,2,3 and 4 years of age, respectively, showing that this feature is not able to respond to individual selection. The authors suggest that, once there is a strong selection pressure for height in the populations evaluated, the reduced genetic variability contributed to these results.

\section{CONCLUSION}

The selection for weight between 440 to 480 days of age (15 months) will be more efficient, due to its higher genetic variance. However, for withers height, the best response to selection is likely to occur if performed near 300 to 340 days of age.

\section{REFERENCES}

ALBUQUERQUE, L.G.; MEYER, K. Estimates of covariance functions for growth from birth to 630 days of age in Nelore cattle. Journal of Animal Science, v.79, p.2776-2786,

Ciência Rural, v.42, n.12, dez, 2012. 
2001a. Available from: <http://jas.fass.org/content/79/11/ 2776.short>. Accessed: Jul. 03, 2012.

ALBUQUERQUE, L.G.; MEYER, K. Estimates of direct and maternal genetic effects for weights from birth to 600 days of age in Nelore cattle. Journal of Animal Breeding and Genetics, v.118, p.83-92, 2001b. Available from: <http:// onlinelibrary.wiley.com/doi/ $10.1046 /$ j. 1439 . 0388.2001.00279.x/full>. Accessed: Nov. 15, 2011. doi: 10.1046/j.1439-0388.2001.00279.x.

BOLDMAN, K.G. et al. A manual for use for MTDFREML: a set of programs to obtain estimates of variance and covariance. Lincoln: Department of Agriculture/Agricultural Research Service, 1995. 120p.

BROWN-DOUGLAS, C.G.; PAGAN, J.D. Body weight, wither height and growth rates in Thoroughbreds raised in America, England, Australia, New Zealand and India. In: PROCEEDINGS OF THE 2006 EQUINE NUTRITION CONFERENCE, 2006, Lexington, KY. Proceedings... Lexington: Equine Nutrition Conference, 2006. 70p. p.15-22.

CAMPOS, V.A.L. et al. Influência de fatores genéticos e ambientais sobre as características produtivas no rebanho equino do Exército Brasileiro. Revista Brasileira de Zootecnia, v.36, p.23-31, 2007. Available from: <http://dx.doi.org/ 10.1590/S1516-35982007000100004>. Accessed: Nov. 2011, 15. doi: 10.1590/S1516-35982007000100004.

DIAS, L.T. et al. Estimação de parâmetros genéticos para peso em diferentes idades para animais da raça Tabapuã. Revista Brasileira de Zootecnia, v.34, p.1914-1919, 2005. Available from: <http:// dx.doi.org/10.1590/S1516-35982005000600015>. Accessed: Dec. 2011, 10. doi: 10.1590/S1516-35982005000600015.

DLog. Normas para o controle dos eqüídeos no exército. Brasília: Ministério da Defesa, 2003. 59p.

DRUML, T. et al. Morphological analysis and effect of selection for conformation in the Noriker draught horse population. Livestock Science, v.115, p.118-128, 2008. Available from: <http://dx.doi.org/10.1016/j.livsci.2007.06.015>. Accessed: Dec. 10, 2011. doi: 10.1016/j.livsci.2007.06.015.

HINTZ, R.L. et al. Estimation of heritabilities for weight, height and front cannon bone circumference of Thoroughbreds. Journal of Animal Science, v.47, p.1243-1245, 1978 Available from: <http://digitalcommons.unl.edu/animalscifacpub/ 335/>. Accessed: Nov. 15, 2011

KOENEN, E.P.C. et al. Genetic-parameters of linear scored conformation traits and their relation to dressage and showjumping performance in the Dutch Warmblood riding horse population. Livestock Production Science, v.43, p.85-94,
1995. Available from: <http://dx.doi.org/10.1016/03016226(95)00010-I>. Accessed: Nov. 15, 2011. doi: 10.1016/ 0301-6226(95)00010-I.

LAWRENCE, T.L.J.; FOWLER, V.R. Growth of farm animals. 2.ed. Aberdeen: $\mathrm{CAB}$ International, 2002. 368p.

LOVSIN, E. et al. Growth dynamics of Lipizzan horses and their comparison to other horse breeds. Pflugers Archives European Journal of Physiology, v.442, supl, p.211-212, 2001. Available from: <http://www.springerlink.com/content/ v1uw3canv7kfqy8n/>. Accessed: Dec. 10, 2011. doi: 10.1007/ s004240100029.

OLIVEIRA, L.A. et al. Estudo de respostas fisiológicas de equinos sem raça definida e da raça quarto de milha às condições climáticas de Teresina, Piauí. Ciência Animal Brasileira, v.9, p.827-838, 2008. Available from: <http:// www.revistas.ufg.br/index.php/vet/article/view/545/4342>. Accessed: Dec. 10, 2011.

RUSTIN, M. et al. Multi-trait animal model estimation of genetic parameters for linear type and gait traits in Belgian Warmblood horse. Journal of Animal Breeding and Genetics, v.126, p.378-386, 2009. Available from: <http:// onlinelibrary.wiley.com/doi/ $10.1111 /$ j. 1439 0388.2008.00798.x/full>. Accessed: Dec. 10, 2011 . doi: 10.1111/j.1439-0388.2008.00798.x.

SAMORE, A.B. et al. Genetic parameters and breeding values for linear type traits in the Haflinger horse. Livestock Production Science, v.52, p.105-111, 1997. Available from: <http:// dx.doi.org/10.1016/S0301-6226(97)00143-7>. Accessed: Nov. 15, 2011. doi: 10.1016/S0301-6226(97)00143-7.

SCHRODERUS, E.; OJALA, M. Estimates of genetic parameters for conformation measures and scores in Finnhorse and Standardbred foals. Journal of Animal Breeding and Genetics, v.127, p.395-403, 2010. Available from: <http:// onlinelibrary.wiley.com/doi/ $10.1111 /$ j . 1439 0388.2010.00856.x/full>. Accessed: Nov. 15, 2011. doi: 10.1111/j.1439-0388.2010.00856.x.

ZECHNER, P. et al. Morphological description of the Lipizzan horse population. Livestock Production Science, v.69, 163177, 2001. Available from: <http://dx.doi.org/10.1016/S03016226(00)00254-2>. Acessed: Nov. 15, 2011. doi: 10.1016/ S0301-6226(00)00254-2.

VERVUERT, I. et al. Growth rates and the incidence of osteochondrotic lesions in Hanoverian warmblood foals. In: EQUINE NUTRITION PHYSIOLOGY SOCIETY SYMPOSIUM, 18., 2003, Michigan, USA. Proceedings... Michigan: Equine Nutrition Physiology Society, 2003. 351p. p.113-114. 